\title{
A Cell for the Ages: Human $\gamma \delta$ T Cells across the Lifespan
}

\author{
Brandi L. Clark ${ }^{1,2}$ and Paul G. Thomas $1,2, *$ (D) \\ 1 Department of Immunology, St. Jude Children's Research Hospital, Memphis, TN 38105, USA; \\ brandi.clark@stjude.org \\ 2 Integrated Biomedical Sciences Program, University of Tennessee Health Science Center, \\ Memphis, TN 38163, USA \\ * Correspondence: paul.thomas@stjude.org
}

Received: 9 October 2020; Accepted: 23 November 2020; Published: 24 November 2020

\begin{abstract}
The complexity of the human immune system is exacerbated by age-related changes to immune cell functionality. Many of these age-related effects remain undescribed or driven by mechanisms that are poorly understood. $\gamma \delta \mathrm{T}$ cells, while considered an adaptive subset based on immunological ontogeny, retain both innate-like and adaptive-like characteristics. This $\mathrm{T}$ cell population is small but mighty, and has been implicated in both homeostatic and disease-induced immunity within tissues and throughout the periphery. In this review, we outline what is known about the effect of age on human peripheral $\gamma \delta \mathrm{T}$ cells, and call attention to areas of the field where further research is needed.
\end{abstract}

Keywords: $\gamma \delta \mathrm{T}$ cells; human; development; age; periphery; passive immunity; reactive immunity; cancer; transplant; cytomegalovirus; influenza; tuberculosis

\section{Introduction}

Age and functionality of the immune system are intricately connected, as has been well established throughout the literature in the fields of both innate and adaptive immunology [1-9]. These differences are often characterized based on three main phases of life: infancy, adulthood, and old age. Interestingly, there tends to be overlap in the immune function on opposite ends of the spectrum-namely that children and the elderly often respond to immune challenges with similar results. That said, the mechanisms behind these responses are quite different in nature. An example of this can be seen when one compares the innate immune responses triggered by Toll-like receptor (TLR) stimulation of infants and the elderly [10]. Both populations are highly susceptible to infection and increased inflammation, yet the underlying mechanisms of these phenomena are unique. Elderly individuals suffer from inflamm-aging, a condition where baseline inflammatory levels are heightened in aging individuals. However, their TLR sensing capabilities are often decreased, preventing a robust inflammatory response at the proper time. In infants, TLR sensors seem to be functioning properly-the difference is that the downstream responses are unique compared to traditional adult responses, including a decrease in TLR-mediated innate effector molecules, an increased susceptibility to oxygen radicals, and differing cytokine production [10].

When considering the effects of aging on the immune system, there are many other factors that should be included—such as environmental conditions and prior antigen exposure [11,12]. Lifestyle choices also contribute to immune aging, as nutrition, pharmacologic intervention, and psychological stress have all been shown to affect the immune system $[13,14]$. For these reasons, chronological age alone is not the most robust correlate for immune aging. To combat these discrepancies, a study published in 2019 outlined a new metric for more accurately determining immune system age, coined 
"IMM-AGE" [15]. This high-dimensional trajectory algorithm allows for a more precise aging of the immune system on an individual basis.

Even as our understanding of the effects of age on the immune system is expanding, there are still many gaps in the field. A notable example of this can be observed in $\gamma \delta \mathrm{T}$ cells. This cell subset of the adaptive immune system uniquely exhibits characteristics of both innate and adaptive immunity, and is often thought to be "bridging the gap" between the two arms of the immune system [16,17]. Age has been associated with functional change in $\gamma \delta \mathrm{T}$ cells in mice and humans [18], but in most studies these effects are too often overlooked, especially in human research. In this review, we outline the reported role that age plays in the human $\gamma \delta \mathrm{T}$ cell response in health and disease, as well as highlighting areas of the field that are sorely lacking an age component.

\section{Passive $\gamma \delta$ T Cell Immunity}

The immune system broadly consists of two arms: innate and adaptive immunity. The innate immune system is considered the first line of defense against pathogens and damage, rapidly responding in a nonspecific manner. The adaptive immune system is slower to respond, and elicits its functions in a pathogen-specific manner. $T$ cells and $B$ cells make up the adaptive compartment and achieve their specificity via their $T$ cell receptor (TCR) and $B$ cell receptor (BCR), respectively. The TCR and BCR are both created by V(D)J Recombination, a semi-random process by which lymphocytes construct their antigen-specific receptors [19]. The TCR is composed of either an alpha and beta chain or a gamma and delta chain, and the combination of all TCRs in an individual is referred to as their TCR repertoire. Analysis of the TCR repertoire can provide insights into antigen reactivity and specificity, as well as history of pathogen exposure [20]. $\alpha \beta$ T cells express CD8 or CD4, and are restricted to recognizing antigenic peptides presented by a Major Histocompatibility Complex (MHC) in a CD3-dependent manner. $\gamma \delta$ T cells were first identified and characterized in the 1980s [21-23], and they are similar to $\alpha \beta$ T cells in many regards. This cell type has a TCR that is also constructed via V(D)J Recombination, and utilizes CD3 to respond in an antigen-specific manner. $\gamma \delta \mathrm{T}$ cells are much less frequent than $\alpha \beta$ T cells, making up only $5-10 \%$ of CD3+ cells in peripheral blood, although they are present at higher frequencies in mucosal tissues. They are MHC-unrestricted, meaning that their recognition of pathogens does not require MHC presentation. Additionally, while $\alpha \beta$ T cells are only able to recognize antigenic peptide fragments, $\gamma \delta \mathrm{T}$ cells can also recognize entire proteins and stress signals. This recognition occurs via Natural Killer (NK) cell receptors and Pattern Recognition Receptors (PRRs), in addition to their TCR. The myriad of receptors expressed by $\gamma \delta \mathrm{T}$ cells allows this population to respond in an innate-like manner to pathogen- and damage-associated molecular patterns (PAMPs and DAMPs) $[17,24]$.

Human $\gamma \delta$ T cells have seven functional T-cell receptor gamma variable region (TRGV)-encoding genes and eight functional T-cell receptor delta variable region (TRDV)-encoding genes [25]. Broadly speaking, these cells are often split into two major groups based on TRDV usage: V $\delta 2+$ and V $\delta 2-$ $\mathrm{T}$ cells [26,27]. The majority of $\mathrm{V} \delta 2+\mathrm{T}$ cells are $\mathrm{V} \gamma 9+$ (Lefranc nomenclature [28], formerly known as $\mathrm{V} \gamma 2+)$, and make up over $90 \%$ of $\gamma \delta \mathrm{T}$ cells in peripheral blood [29]. Traditionally regarded as the innate-like subset, $\mathrm{V} \gamma 9+\mathrm{V} \delta 2+$ respond to both endogenous and exogenous phosphoantigens (pAgs), such as (E)-4-hydroxy-3-methyl-but-2-enyl pyrophosphate (HMB-PP) and Isopentenyl pyrophosphate (IPP) [25]. They utilize a semi-invariant, oligoclonal repertoire [29], and their rapid BTN3A1/BTN2A1-dependent functionality occurs even in the absence of previous exposure [30-33]. $\mathrm{V} \delta 2-\gamma \delta \mathrm{T}$ cells are largely $\mathrm{V} \delta 1+$, although $\mathrm{V} \delta 3+$ and $\mathrm{V} \delta 5+$ segments are also observed. Unlike $\mathrm{V} \gamma 9+\mathrm{V} \delta 2+\mathrm{T}$ cells, $\mathrm{V} \delta 2-\mathrm{T}$ cells pair with a more diverse array of $\mathrm{V} \gamma$ segments [34]. This subset is predominant in mucosal tissues, while only a small percentage are present in peripheral blood $[25,35,36]$. $\mathrm{V} \delta 2-\mathrm{T}$ cells have been shown to exhibit characteristics of memory responses seen in traditional $\alpha \beta \mathrm{T}$ cells, such as antigen-driven clonal expansions and differentiation from naive to effector phenotypes $[26,27,37,38]$, and they are thus considered adaptive-like in nature. V $\delta 2-\mathrm{T}$ cells have the 
ability to recognize tumor cells and virally-infected cells, yet the field is sorely lacking in definitive ligand recognition data for this subset [39].

Both peripheral and tissue resident $\gamma \delta \mathrm{T}$ cells maintain age-specific functionality and distribution, even in the absence of underlying conditions [40-43]. $\gamma \delta \mathrm{T}$ cells are observed as early as 12.5 weeks gestation [44], and there are obvious age-related differences when tracking the frequency and number of $\gamma \delta \mathrm{T}$ cells across the lifespan. Both frequency and number peak in adulthood, and decrease in aged individuals [40,43-45]. Age- and tissue-specific signatures of the repertoire are present as well [46], and the developmental waves of $\gamma \delta$ T cells and their TCR repertoires have been recently reviewed [30]. The fetal and infant $\mathrm{V} \gamma 9+\mathrm{V} \delta 2+$ repertoires are public, meaning that certain TCR sequences are present across individuals. Non- $\mathrm{V} \gamma 9+\mathrm{V} \delta 2+$ repertoires are public during gestation, and become private, or unique to the individual, after birth [42,47]. While the majority of $\gamma \delta \mathrm{T}$ cells present mid-gestation are $\mathrm{V} \gamma 9+\mathrm{V} \delta 2+, \mathrm{V} \delta 2-\mathrm{T}$ cells predominate the periphery from late gestation through early infancy $[34,41,42,44]$. V $\delta 2+T$ cells are present at this time as well, but are not primarily paired with $\mathrm{V} \gamma 9+[40,44]$. $\mathrm{V} \gamma 9+\mathrm{V} \delta 2+\mathrm{T}$ cells begin populating the periphery quickly after birth-the expansion occurs at around 10 weeks of age-and the proportionality seen in adulthood is established by approximately 6 years of age [42,48]. It is believed that the reason for this expansion is two-fold: increased pathogen exposure immediately after birth, and the heightened protective role exhibited by neonatal $\gamma \delta$ T cells due to delayed maturation of the $\alpha \beta$ T cell compartment [44]. The V $\gamma 9+\mathrm{V} \delta 2+$ expansion during infancy and adolescence is due to proliferation, not increased thymic output $[40,48]$. Additionally, these cells have repertoires that trace back to fetal $\gamma \delta \mathrm{T}$ cells based on publicity and a decreased amount of $\mathrm{N}$ insertions [34,41,42,44]. While adult $\gamma \delta \mathrm{T}$ cells show a marked narrowing of the repertoire via decreased segment usage, diversity, and publicity, $\mathrm{V} \gamma 9+\mathrm{V} \delta 2+\mathrm{T}$ cells maintain publicity in the TRGV repertoire, even though the TRDV repertoire is private [46,47]. Age-dependent contraction of $\gamma \delta \mathrm{T}$ cells is limited to the $\mathrm{V} \gamma 9+\mathrm{V} \delta 2+$ compartment, while $\mathrm{V} \delta 2-\mathrm{T}$ cells are maintained, if not expanded, upon aging $[45,49,50]$. Segment usage within the repertoire is also correlated with age and ancestry, as it has been shown that variations in V $\delta 1+\mathrm{T}$ cell frequencies are associated with ethnicity (including African, European, and Asian populations) [34,41,45,49,51]. Males have been shown to have more overall $\gamma \delta \mathrm{T}$ cells than females, and an increase in V $\delta 2+\mathrm{T}$ cells is responsible for this difference [49]. The age-dependent distribution and functionality of peripheral $\gamma \delta \mathrm{T}$ cells is outlined in Figure 1.

When characterizing $\gamma \delta$ T cells using activation markers typically studied in $\alpha \beta$ T cells [43], it has been reported that virtually all circulating $\mathrm{V} \gamma 9+\mathrm{V} \delta 2+\mathrm{T}$ cells lose their naive phenotype within the first year of life $[40,45,52]$. V82- cells at epithelial sites typically maintain a naive phenotype longer, often throughout childhood [40]. The acquisition of cytotoxic markers is variable based on $\gamma \delta$ T cell population, location, age, infection status, and even gender and ancestry $[38,42,45,49,53]$. However, it has been reported that naive markers and activation markers are remarkably comparable between neonates and adults [40]. Cell surface markers alone are not sufficient to accurately assess cytotoxic function, so multiple studies have analyzed the effector functions of $\gamma \delta \mathrm{T}$ cells at different ages. Interestingly, younger individuals (fetus through 1.5 years of life) have $\mathrm{V} \gamma 9+\mathrm{V} \delta 2+\mathrm{T}$ cells that are pathogen-reactive in a manner similar to adults, as determined by interferon gamma (IFN $\gamma$ ), granzyme, and perforin production following stimulation [40,44]. While this responsiveness is less robust compared to adult $\mathrm{V} \gamma 9+\mathrm{V} \delta 2+\mathrm{T}$ cells, any degree of responsiveness in utero, often considered a more sterile environment, is indicative of functional pre-programming that is exposure independent. $\mathrm{V} \gamma 9+\mathrm{V} \delta 2+\mathrm{T}$ cells expanding through infancy and adolescence have cytotoxic effects that are comparable to adults, such as the expression of both Perforin and Granzyme B [42]. Upon aging, the responsiveness of this subset to stimulation deteriorates. Aging $\mathrm{V} \gamma 9+\mathrm{V} \delta 2+\mathrm{T}$ cells express upregulated $\mathrm{CD} 69$, and have higher basal expression of tumor necrosis factor alpha $(\mathrm{TNF} \alpha)$ compared to younger individuals. However, these cells show a decreased responsiveness to IPP in culture based on TNF $\alpha$ production [54]. These results reveal that $\gamma \delta \mathrm{T}$ cells are not immune to the effects of immunosenescence and inflamm-aging. Disease history is another driver of $\gamma \delta \mathrm{T}$ cell functionality, and in the following section we will outline the 
effect of age on disease-responsive $\gamma \delta$ T cells. For a more detailed description of $\gamma \delta \mathrm{T}$ cell effector functions in both health and disease with reference to age, see Table 1. It is important to note that effector functionality of $\gamma \delta \mathrm{T}$ cells has not been thoroughly investigated with respect to age.

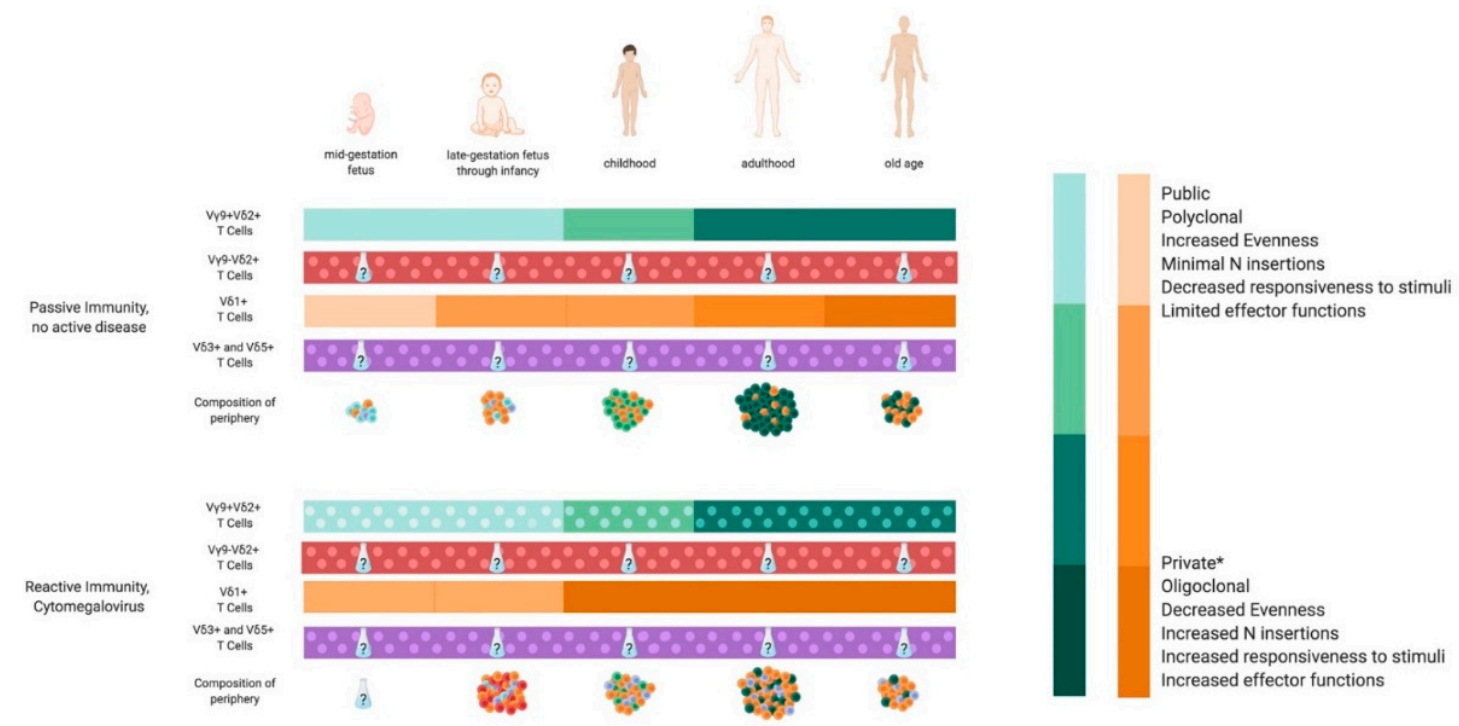

Figure 1. An overview of the effects of age and cytomegalovirus (CMV) on the peripheral $\gamma \delta \mathrm{T}$ cell compartment in humans, based on segment usage. Due to the lack of data concerning age and segment usage over time in the context of most diseases, human cytomegalovirus (HCMV) is the only disease state reported in the figure. Solid colors are indicative of reported data, while patterned colors signify a lack of information. This lack of information stems from either insufficient data on the specified subset, or that the effects of HCMV on the population have not been characterized because the subset in question has not been found to be directly involved in the anti-HCMV immune response. Created using BioRender.com * $\mathrm{V} \gamma 9+\mathrm{V} \delta 2+\mathrm{T}$ cells become increasingly private with age, but public TRGV sequences persist into adulthood and beyond while TRDV sequences become fully private.

Table 1. Overview of reported $\gamma \delta \mathrm{T}$ cell effector molecules based on age and location in health and disease.

\begin{tabular}{|c|c|c|c|c|}
\hline Subset(s) & Location & Age & Effector Molecules & Disease State * \\
\hline $\mathrm{V} \delta 2+$ & Periphery & Cord Blood & $\operatorname{IFN} \gamma * *$ & Homeostasis [55] \\
\hline $\mathrm{V} \delta 2+$ & Periphery & Neonates (14 d) & $\mathrm{IFN} \gamma$ & Homeostasis [55] \\
\hline $\mathrm{V} \delta 1+\mathrm{V} \delta 2+$ & Periphery & $\begin{array}{c}\text { Infant } \\
(4 \mathrm{~m})\end{array}$ & IFN $\gamma$, perforin & Homeostasis [53] \\
\hline $\mathrm{V} \gamma 9+\mathrm{V} \delta 2+$ & Periphery & $\begin{array}{c}\text { Infant } \\
(1 \mathrm{y})\end{array}$ & IFN $\gamma$ & Homeostasis [53] \\
\hline $\mathrm{V} \delta 2+$ & Periphery & $\begin{array}{l}\text { Children } \\
(2-5 \mathrm{y})\end{array}$ & IFN $\gamma$ & Homeostasis [55] \\
\hline $\mathrm{V} \gamma 9+\mathrm{V} \delta 2+$ & $\begin{array}{l}\text { Periphery, Cerebrospinal } \\
\text { fluid }\end{array}$ & $\begin{array}{l}\text { Children } \\
\text { (3-14 y) }\end{array}$ & IL-17A ** & Bacterial meningitis [56] \\
\hline $\mathrm{V} \gamma 9+\mathrm{V} \delta 2+$ & Periphery, Tonsils & $\begin{array}{l}\text { Children } \\
\text { (9-14 y) }\end{array}$ & IL-2, IL-4, IL-10 & $\begin{array}{l}\text { Tonsillectomy patients [57] } \\
\text { (Caccamo 2006) }\end{array}$ \\
\hline $\mathrm{V} \gamma 9+\mathrm{V} \delta 2+$ & Periphery & Adult & $\begin{array}{l}\text { IFN } \gamma, \text { TNF } \alpha{ }^{* *}, \mathrm{IL}-2, \\
\text { IL-4, IL-10, IL-17A }\end{array}$ & Homeostasis $[26,53,56-61]$ \\
\hline $\mathrm{V} \delta 1+$ & Periphery & Adult & Perforin, granzymes & Homeostasis [26] \\
\hline Unspecified & Periphery & Adult & $\begin{array}{l}\text { IFN } \gamma, \text { TNF } \alpha, \text { IL-6, } \\
\text { IL-17A, IL-10 }\end{array}$ & Homeostasis [59] \\
\hline Unspecified & Mucous Membrane & Adult & $\begin{array}{l}\text { IL-10, TGF- } \beta \text { **, TNF } \alpha \text {, } \\
\text { IFN } \gamma, \text { IL-4, IL-2 }\end{array}$ & Pregnancy [62] \\
\hline $\mathrm{V} \gamma 9+\mathrm{V} \delta 2+$ & Periphery & Adult & IFN $\gamma$, TNF $\alpha$, IL-17A & Rheumatic disease [63] \\
\hline
\end{tabular}


Table 1. Cont.

\begin{tabular}{|c|c|c|c|c|}
\hline Subset(s) & Location & Age & Effector Molecules & Disease State * \\
\hline $\mathrm{V} \gamma 9+\mathrm{V} \delta 2+$ & Periphery & Adult & $\underset{\text { CCL5 }}{\operatorname{IFN} \gamma, \text { CCL3 }}{ }^{* *}, \mathrm{CCL} 4$, & Influenza [64-66] \\
\hline $\mathrm{V} \gamma 9+\mathrm{V} \delta 2+$ & Periphery & Adult & $\mathrm{IFN} \gamma, \mathrm{TNF} \alpha$ & Legionellosis [67] \\
\hline $\mathrm{V} \gamma 9+\mathrm{V} \delta 2+$ & Periphery & Adult & $\mathrm{IFN} \gamma$ & $\begin{array}{l}\text { Human immunodeficiency virus } \\
\text { (HIV) [68] }\end{array}$ \\
\hline $\mathrm{V} \gamma 9+\mathrm{V} \delta 2+$ & Lesions & Adult & $\begin{array}{l}\text { IL-17A, IL-8, IFN } \gamma, \\
\text { TNF } \alpha\end{array}$ & Psoriasis [69] \\
\hline $\mathrm{V} \gamma 9+\mathrm{V} \delta 2+$ & Tumor-infiltrating & Adult & $\mathrm{IFN} \gamma, \mathrm{TNF} \alpha$ & Colon carcinoma [70] \\
\hline V $\delta 2+$ & Periphery & Adult & IFN $\gamma$, IL-17A & Hepatitis B virus (HBV) [71,72] \\
\hline V $\delta 2-$ & Periphery & Adult & $\mathrm{IFN} \gamma, \mathrm{TNF} \alpha$ & $\begin{array}{c}\text { Human cytomegalovirus } \\
\text { (HCMV) }[64,73,74]\end{array}$ \\
\hline $\mathrm{V} \delta 1+$ & Periphery, Synovial fluid & Adult & IFN $\gamma$, IL-4 & Rheumatic disease [63] \\
\hline Unspecified & Periphery & Adult & IFN $\gamma, \mathrm{TNF} \alpha, \mathrm{IL}-4, \mathrm{IL}-10$ & $\begin{array}{c}\text { Mycobacterium tuberculosis } \\
{[75,76]}\end{array}$ \\
\hline Unspecified & Periphery & Adult & IL-17A, TNF $\alpha$ & $\begin{array}{l}\text { Various bacterial infections, } \\
\text { Plasmodium falciparum [64] }\end{array}$ \\
\hline Unspecified & Tumor-infiltrating & Adult & $\begin{array}{l}\text { IFN } \gamma, \text { TNF } \alpha, \text { IL-17A, } \\
\text { IL- } 4, \text { TNF } \beta\end{array}$ & $\begin{array}{l}\text { Miscellaneous adult cancers } \\
{[[77,78]}\end{array}$ \\
\hline Unspecified & Liver-derived celllines & Adult & IFN $\gamma, \mathrm{TNF} \alpha, \mathrm{IL}-8$ & Viral hepatitis [79] \\
\hline
\end{tabular}

${ }^{*}$ Many of the reported effector functions are derived from in vitro treatments (e.g., stimulation with virus, phorbol myristate acetate (PMA)/Ionomycin, phosphoantigen ( $\mathrm{pAg}$ ), etc.). Some studies were done using primary cell lines. ** IFN $=$ interferon, IL = interleukin, TNF = tumor necrosis factor, $\mathrm{CCL}=\mathrm{C}-\mathrm{C}$ motif chemokine ligand

\section{Reactive $\gamma \delta \mathrm{T}$ Cell Immunity}

\subsection{Cancer}

The role of human $\gamma \delta \mathrm{T}$ cells in cancer is widely variable based on the type and location. $\gamma \delta \mathrm{T}$ cells are able to infiltrate the tumor microenvironment, as observed in melanoma [77], rectal cancer [80], and breast cancer [81]. The anti-tumor effects of $\mathrm{V} \gamma 9+\mathrm{V} \delta 2+\mathrm{T}$ cells are present early in life, as a study in 1990 revealed that cord blood $\mathrm{V} \gamma 9+\mathrm{V} \delta 2+\mathrm{T}$ cells were responsive to a Burkitt's lymphoma cell line [82]. Both $\mathrm{V} \gamma 9+\mathrm{V} \delta 2+$ and $\mathrm{V} \delta 1+\mathrm{T}$ cells exhibit anti-tumor effects in both TCR-dependent and NK cell receptor (NKR)-dependent mechanisms, with downstream effects including perforin and granzyme expression, tumor necrosis factor-related apoptosis-inducing ligand (TRAIL) expression, human apoptosis-related factor ligand (FASL)-mediated apoptosis, and antibody-dependent cell-mediated cytotoxicity (ADCC) [31]. The majority of studies concerning the efficacy of $\gamma \delta \mathrm{T}$ cells in cancer treatment focus on the $\mathrm{V} \gamma 9+\mathrm{V} \delta 2+\mathrm{T}$ cell subset [83-87], due to the incomplete understanding of $\mathrm{V} \delta 1+$ $\mathrm{T}$ cell recognition. While some $\mathrm{V} \delta 1+\gamma \delta \mathrm{T}$ cells can promote an anti-tumor environment as mentioned above, others appear to promote a pro-tumor environment [88]. IL-17A-producing $\gamma \delta \mathrm{T}$ cells (T $\gamma \delta 17$ cells) are the primary pro-tumor $\gamma \delta \mathrm{T}$ cell subset. These cells are typically V $\delta 2-$, although a small percentage of $\mathrm{V} \gamma 9+\mathrm{V} \delta 2+\mathrm{T}$ cells have been shown to express IL-17A [56,58]. Broadly speaking, $\mathrm{T} \gamma \delta 17$ cells exhibit immunosuppressive functions and promote tumor growth. This immunosuppression can target T cells and dendritic cells, allowing tumor cells to escape immune surveillance $[80,88,89]$. IL-17A production can dismantle the anti-tumor functionality of IFN $\gamma$-producing $\gamma \delta \mathrm{T}$ cells, and T $\gamma \delta 17$ cells have been associated with tumor progression and poor outcomes in multiple tumor types [31,88]; however, the mechanism by which this occurs in humans is not fully understood. In addition to IL-17A production, IL-4 expression has been shown to inhibit the anti-tumor response of $\mathrm{V} \gamma 9+\mathrm{V} \delta 2+$ $\mathrm{T}$ cells via the promotion of IL-10-producing V $81+\mathrm{T}$ cell growth [59]. It is important to note that these rules are not hard and fast, as a small number of mouse studies have implicated $\mathrm{T} \gamma \delta 17$ cells in a tumor-protective role [88].

On their own, none of the aforementioned data point to an age-related association between $\gamma \delta \mathrm{T}$ cells and cancer immunity. Using the knowledge that $\mathrm{V} \delta 1+\mathrm{T}$ cells are predominant in the periphery of infants and $\mathrm{V} \gamma 9+\mathrm{V} \delta 2+\mathrm{T}$ cells largely constitute the periphery of adults, one could speculate that adulthood promotes an anti-tumor functionality of $\gamma \delta \mathrm{T}$ cells. Since the $\gamma \delta \mathrm{T}$ cell contraction in the elderly is restricted to $\mathrm{V} \gamma 9+\mathrm{V} \delta 2+\mathrm{T}$ cells while the $\mathrm{V} \delta 2$ - compartment remains intact, one could additionally speculate that aging promotes a pro-tumor environment. The same could be 
said for both tissue-resident and mucosal $\gamma \delta \mathrm{T}$ cells, as these locations are home to V $\delta 1+\mathrm{T}$ cells and IL-17A-producing $\gamma \delta \mathrm{T}$ cells, respectively. Additionally, aging results in increased inflammation, and it is likely that $\mathrm{T} \gamma \delta 17$ cells elicit their pro-tumor functions in an inflammation-dependent manner [88]. However, this inference is muddied by the reality that both subsets have been shown to exhibit proand anti-tumor immunity, and we were not able to find a study that has reported the impact of age on the $\gamma \delta \mathrm{T}$ cell response to cancer.

\subsection{Transplant}

$\gamma \delta$ T cells have been studied in the context of transplant since the 1990s, and are an important subset to consider in the field due to TCR-dependent tissue localization and a lack of MHC restriction [90]. They have been shown to quickly reconstitute along with NK cells following allogeneic hematopoietic stem cell transplant (HSCT), and are believed to effectively fill the role of $\alpha \beta$ T cells, which take longer to recover [91-94]. $\gamma \delta \mathrm{T}$ cells, in the context of transplant, have been reviewed more thoroughly elsewhere $[73,90,95]$, revealing their multifaceted effect on overall success and survival. Following HSCT, positive correlations have been reported between elevated $\gamma \delta \mathrm{T}$ cell numbers and increased survival rate, while a negative correlation has been reported between $\gamma \delta \mathrm{T}$ cell numbers and graft-versus-host-disease (GVHD) severity. When immune ablation for transplant results in primary human cytomegalovirus (HCMV) infection or reactivation, $\gamma \delta \mathrm{T}$ cells are typically associated with favorable outcomes. Despite these data, $\gamma \delta$ T cells have also been correlated with negative transplant outcomes, as studies in the 1990s revealed that $\mathrm{V} \delta 2+\mathrm{T}$ cells were enriched in patients with acute GVHD three months post-transplant [73]. It has been reported that $\mathrm{V} \gamma 9+\mathrm{V} \delta 2+\mathrm{T}$ cells are reconstituted with a highly similar repertoire following HSCT, while V $\delta 1+T$ cells exhibit a skewed repertoire [96]. The results of a pediatric HSCT study in 2015 aligned with reported adult HSCT data, where increased $\gamma \delta \mathrm{T}$ cell reconstitution was significantly correlated with both increased event-free survival and decreased post-HSCT infections [92]. While we were unable to locate a study outlining the unique features distinguishing pediatric and adult $\gamma \delta \mathrm{T}$ cell responses following transplant, Witte et al. reported that the transplant graft donor age can affect $\gamma \delta \mathrm{T}$ cell reconstitution. For example, V $\delta 2+\mathrm{T}$ cells are virtually absent in patients receiving umbilical cord grafts [94]. Based on the age- and infection-dependent distribution of $\gamma \delta \mathrm{T}$ cell subsets, we hypothesize that donor age and herpesvirus serostatus would greatly influence the repertoire of reconstituted $\gamma \delta \mathrm{T}$ cells, shaping the immune system for years to come.

\subsection{Infectious Disease}

Numerous studies have highlighted the importance of $\gamma \delta$ T cells in infectious disease. Their function is determined by factors including route of infection and tissue dissemination. Comprehensive overviews of $\gamma \delta$ T cells in viral and bacterial infections have been published over the years [64,97-99], yet there is minimal mention of the role that age plays in these responses. In this section, we intend to outline the effects of age on the human $\gamma \delta \mathrm{T}$ cell response to pathogens that have been reported.

\subsubsection{Cytomegalovirus}

Human cytomegalovirus (HCMV) is a latent herpesvirus with immunomodulatory capabilities across the lifespan [100-102]. This virus has an infectivity rate of 30-90\% [103], and it is estimated that one in three children are infected by the age of 5 [104]. The age-dependent immune response to HCMV is documented in multiple cell types, including CD8+ T cells and NK cells [102,105-110]. It is well-established that $\gamma \delta \mathrm{T}$ cells also respond to HCMV, whether in a natural infection/latency/reactivation cycle $[103,111,112]$, or in response to the immune ablation of transplant patients $[73,90,113,114]$. While $\mathrm{V} \gamma 9+\mathrm{V} \delta 2+\mathrm{T}$ cells are typically the most prominent $\gamma \delta \mathrm{T}$ cell subset in the periphery, CMV has been shown to shift that axis. This is due to the expansion and response of V $\delta 2-\mathrm{T}$ cells (typically V $\delta 1+$ and V $83+)[74,115,116]$.

The effect of age on $\gamma \delta$ T cell immunity to HCMV is arguably the most well-characterized [103,114], and is outlined in Figure 1. When HCMV infection occurs in utero, an expansion, activation, and CDR3 
restriction of $\mathrm{V} \gamma 9-\mathrm{T}$ cells is seen, including $\mathrm{V} \delta 1+, \mathrm{V} \delta 2+$ and $\mathrm{V} \delta 3+\mathrm{T}$ cells $[103,114,117]$. A public $\mathrm{V} \gamma 8+\mathrm{V} \delta 1+$ clone has also been identified in the fetal response to HCMV as early as 21 weeks of gestation [117]. In adults, HCMV has no observable effect on V $\delta 2+T$ cells [103], and the V $\gamma 8 V \delta 1 \mathrm{~T}$ cell compartment is unaffected by HCMV serostatus [114]. Importantly, even the public fetal V $\gamma 8+\mathrm{V} \delta 1+$ clone is absent in the HCMV+ adults [117]. The most striking effect of HCMV on $\gamma \delta \mathrm{T}$ cells in aging individuals is within the V $\delta 2-\mathrm{T}$ cell compartment, even after the clearance of lytic infection $[38,114]$. As mentioned previously, aging results in a decrease in $\gamma \delta \mathrm{T}$ cell frequency and number. In the absence of HCMV, this decrease is observed in both V $\delta 2+$ and V $\delta 2$ - compartments [74,115], although some studies report that the age-dependent contraction of $\gamma \delta \mathrm{T}$ cells is limited to the $\mathrm{V} \gamma 9+\mathrm{V} \delta 2+\mathrm{T}$ cell compartment alone $[45,49,50,112]$. In the presence of HCMV, the V $\delta 2+\mathrm{T}$ cell compartment shrinks as expected, but the V82- T cell compartment remains largely unchanged, if not expanded [103,112,113,115]. Additionally, it has been reported that CMV seropositive individuals maintain a consistent V $\delta 1+$ population that is not affected by age to the same degree as the same compartment in seronegative individuals $[115,116]$. In response to $\mathrm{HSCT}, \mathrm{V} \delta 1+\mathrm{T}$ cells robustly respond to CMV reactivation, in a manner that is not observed in CMV- individuals, or in CMV- EBV+ patients [114]. A study published in 2013 argued that the age-dependent shaping of $\gamma \delta \mathrm{T}$ cells in elderly individuals is almost exclusively driven by HCMV serostatus [116].

The HCMV-driven mobilization of $\gamma \delta \mathrm{T}$ cells occurs in both immunocompetent and immunocompromised individuals [38]. To date, studies analyzing the $\gamma \delta \mathrm{T}$ cell response to active HCMV in vivo are all performed in a transplant setting, studying reactivation. This is because it is virtually impossible to determine when primary HCMV infection occurs in healthy individuals. However, studying both activation status and cytotoxic effects of seropositive individuals in vitro reveals a long-term signature on $\gamma \delta \mathrm{T}$ cells. V $\delta 1+\mathrm{T}$ cells have been shown to both kill HCMV-infected cells and limit viral propagation via the expression of TNF $\alpha[103,116,118]$. HCMV-activated V $\delta 2-T$ cells also express IFN $\gamma$ [27,40,103], and the virus drives V $\delta 2-\mathrm{T}$ cells from consisting of both naive and effector memory cells to being predominantly effector memory [74]. Fetal $\gamma \delta \mathrm{T}$ cells responding to HCMV were also able to express IFN $\gamma$, and they differentiated into an activated status comparable with CD8 + T cells [117]. Candidate ligands for V81+ T cells have been identified, and they are diverse in nature [26]. One in particular, endothelial protein $C$ receptor (EPCR), expressed on HCMV-infected cells, has been directly recognized by a $\mathrm{V} \gamma 4+\mathrm{V} \delta 5+$ clone $[39,119]$. While we could not find any data on the role of age and ligand recognition in CMV infection, the data outlined in this section clearly indicate an interconnectedness between HCMV, $\gamma \delta \mathrm{T}$ cells, and age.

\subsubsection{Influenza}

It has been well-established that age has a dramatic effect on the immune response to influenza [120122]. This immunomodulation is seen in both the ability to clear the virus, as well as vaccination efficacy $[123,124]$. The $\gamma \delta \mathrm{T}$ cell response to influenza is vastly different when compared to the HCMV response. Where $\mathrm{V} \delta 2-\mathrm{T}$ cells are the main HCMV responders, $\mathrm{V} \gamma 9+\mathrm{V} \delta 2+\mathrm{T}$ cells are the primary responders in both human and avian influenza virus infection $[46,65,125,126]$. The majority of studies into the $\gamma \delta \mathrm{T}$ cell effector response to influenza are performed in vitro, using different forms of stimulation. $\mathrm{V} \gamma 9+\mathrm{V} \delta 2+\mathrm{T}$ cells cultured with pAgs that are both endogenous $[125,126]$ and exogenous [127,128], as well as cells incubated with virus, have potent cytotoxic effects against influenza-infected cells. This is primarily accomplished via IFN $\gamma$ production by the stimulated $\mathrm{V} \gamma 9+\mathrm{V} \delta 2+\mathrm{T}$ cells. pAg stimulation does seem to increase the potency of influenza-reactive $\mathrm{V} \gamma 9+\mathrm{V} \delta 2+$ $\mathrm{T}$ cells, and it has been proposed to use pAg treatment in patients as a means to increase $\gamma \delta \mathrm{T}$ cell reactivity $[65,127]$. All of the aforementioned studies utilized $\gamma \delta \mathrm{T}$ cells isolated from healthy donors, presumably adults, so no correlations with age can be made. A recent study in 2019 compared the adult $\gamma \delta \mathrm{TCR}$ repertoire between healthy and influenza-infected adults, revealing that influenza-reactive $\mathrm{V} \gamma 9+\mathrm{V} \delta 2+\mathrm{T}$ cells exhibit an enrichment of public $\mathrm{V} \gamma 9+$ clonotypes with IFN $\gamma$-production capabilities [46]. Interestingly, the comparison also revealed a public $V \gamma 9+$ CDR3 
sequence in influenza-responsive cells that was present in all healthy cord blood samples and adult donors, but not in every healthy elderly donor [46]. Peripheral $\gamma \delta \mathrm{T}$ cells are also able to respond to influenza vaccination in an age-influenced manner, as younger adult populations exhibit a more robust response when compared to elderly individuals [129]. That said, the human $\gamma \delta \mathrm{T}$ cell field is still vastly underrepresented in studies concerning age and its role in influenza responses.

In CD8+ T cell biology, the presence of CMV can positively affect the immune response to influenza in both mice and humans [124]. This effect was age-specific, as increased age led to a decreased responsiveness in CD8+ T cells, even in the presence of CMV. Age is an important factor in understanding how co-infection shapes the immune system [130,131], yet $\gamma \delta \mathrm{T}$ cells are sorely underrepresented in co-infection studies. One could speculate that there may be a similar effect of CMV on influenza-responsive $\gamma \delta \mathrm{T}$ cells; however, these two viruses elicit responses from different $\gamma \delta$ $\mathrm{T}$ cell subsets. Additionally, age has a unique influence on each of the two $\gamma \delta \mathrm{T}$ cell compartments in question.

\subsubsection{Tuberculosis}

The effects of both Mycobacterium tuberculosis (Mtb) infection and Bacillus Calmette-Guérin (BCG) vaccination on $\gamma \delta \mathrm{T}$ cells have been studied since the late 1900s [42,132-134], and $\mathrm{V} \gamma 9+\mathrm{V} \delta 2+\mathrm{T}$ cells are the primary subset of $\gamma \delta$ T cells that respond to tuberculosis (TB) infection [75,135]. TB has been shown to shape the $\mathrm{V} \gamma 9+\mathrm{V} \delta 2+\mathrm{TCR}$ repertoire, as TB patients have a CDR3 $\delta$ that is more polyclonal than healthy donors [136]. Additionally, novel CDR3 sequences were predominant in TB patients alone [136]. A public V $\delta 2+$ CDR3 has been reported across adult TB patients [76], and potential ligands have been identified as well [135-137]. BCG vaccination has also been shown to elicit a robust $\mathrm{V} \gamma 9+\mathrm{V} \delta 2+\mathrm{T}$ cell response in adults [138,139], and challenges using TB antigens in vitro resulted in a memory-like expansion of IFN $\gamma$-producing $\mathrm{V} \gamma 9+\mathrm{V} \delta 2+\mathrm{T}$ cells [37]. This response seems to be age-specific, because vaccination early in life does not affect the expansion and activation of neonatal $\mathrm{V} \gamma 9+\mathrm{V} \delta 2+\mathrm{T}$ cells [42], although $\mathrm{V} \delta 2+\mathrm{T}$ cells from cord blood are able to respond in vitro to both exogenous BCG and heat-inactivated $M t b[140,141]$. Generally, age has been found to be a factor in the response to TB [142,143], especially in the elderly due to increased basal inflammation [144]; however, the role of $\gamma \delta$ T cells in this age-dependent response is not fully elucidated.

\subsubsection{Miscellaneous Microbes}

The $\gamma \delta \mathrm{T}$ cell response to bacteria is innate-like in nature, and also involves $\mathrm{V} \gamma 9+\mathrm{V} \delta 2+\mathrm{T}$ cells $[67,99]$. This compartment responds to both foreign (HMB-PP) and self (IPP) pAgs [97,145]. It is believed that the microbe-driven response of $\gamma \delta \mathrm{T}$ cells is germline encoded, as enrichment of pAg-reactive $\mathrm{V} \gamma 9+\mathrm{V} \delta 2+\mathrm{T}$ cells is present in the fetus during the second trimester [44]. This responsiveness is comparable to what is seen immediately after birth [146], indicating that microbial exposure is not necessary to elicit a response. These fetal cells express a public germline sequence seen in $50 \%$ of $\mathrm{V} \gamma 9+\mathrm{V} \delta 2+\mathrm{T}$ cells, and they are able to rapidly respond to pAg stimulation [44]. As was true with influenza-responsive $\mathrm{V} \gamma 9+\mathrm{V} \delta 2+\mathrm{T}$ cells, the majority of human studies concerning the $\gamma \delta \mathrm{T}$ cell responsiveness to microbes is accomplished in vitro, typically utilizing endogenous and/or exogenous pAgs. Because of this, the field is sorely lacking in age-specific data, especially when considering how microbial infections shape the $\gamma \delta \mathrm{TCR}$ repertoire and effector functions across the lifespan.

\subsubsection{Miscellaneous Chronic Infections}

Chronic infections uniquely shape the immune system, and the interplay between age, coinfection, and disease is dynamic in nature. Not all chronic viral infections are created equally, and can be loosely sorted into three categories: latent, smoldering, and persistent [131]. $\gamma \delta \mathrm{T}$ cells have been implicated in the immune response to chronic viruses in each of these categories, and their functionality is contextual. For example, $\mathrm{V} \gamma 9+\mathrm{V} \delta 2+\mathrm{T}$ cells retain the ability to both kill and inhibit replication of cells infected with latent viruses like Epstein-Barr virus (EBV) and herpes simplex virus (HSV) $[64,99,147]$. 
As outlined above, HCMV is a smoldering chronic infection in which $\gamma \delta$ T cells have a lasting effect that is age-dependent. $\gamma \delta \mathrm{T}$ cells have also been implicated in the immune response to human immunodeficiency virus (HIV), hepatitis B virus (HBV), and hepatitis C virus (HCV), all of which are persistent chronic viruses $[71,79,147,148]$. However, the functionality of $\gamma \delta \mathrm{T}$ cells in each of these instances is unique, and in some cases even conflicting [149]. With the exception of murine cytomegalovirus (MCMV), there is limited data reporting the effects of age on chronic viral immunity. One such study, which characterized $\gamma \delta \mathrm{T}$ cell inhibitory receptor signatures in HIV infection, identified a link between elevated inflammation and aviremic HIV that is exacerbated in aging individuals [150]. There is a general paucity of human studies investigating the $\gamma \delta \mathrm{T}$ cell response to chronic viruses, making it difficult to speculate about a pattern of $\gamma \delta \mathrm{T}$ cell effector functionality across chronic infections based on segment usage, but this should be an area for further research in $\gamma \delta \mathrm{T}$ cell biology.

\section{Discussion}

$\gamma \delta \mathrm{T}$ cells have been implicated in a multitude of other disease states, including the viruses West Nile and SARS-CoV-2 [151-153], parasitic infections including Plasmodium falciparum [154], and non-infectious diseases such as multiple sclerosis and arthritis [155-157]. Since no age-dependent $\gamma \delta \mathrm{T}$ cell responses are reported for these disease states, they fall outside the scope of this review. While models of immune functionality and aging in rodents are much more well-established, humans were the primary focus of this review because there is not a subset of $\gamma \delta \mathrm{T}$ cells in mice that are pAg-reactive and comparable to human $\mathrm{V} \gamma 9+\mathrm{V} \delta 2+\mathrm{T}$ cells [148]. A more complete understanding of the relationship between age and $\gamma \delta \mathrm{T}$ cell functionality in health and disease requires a deeper inter-species analysis that includes both $\gamma \delta \mathrm{T}$ cell-low (humans, mice) and $\gamma \delta \mathrm{T}$ cell-high (cattle, sheep, chickens, rabbits) species [16]. Until then, we have outlined clear age-dependent responses in $\gamma \delta \mathrm{T}$ cells, both in passive and reactive immunity. Additionally, we have highlighted gaps in the field that clearly indicate there is much left to explore concerning how age affects $\gamma \delta \mathrm{T}$ cells. To fully understand the complexity of the immune system across the lifespan, a clear understanding of this cell type is necessary.

Author Contributions: Writing—original draft preparation, review, editing, B.L.C.; writing—review, editing, P.G.T.; funding acquisition, P.G.T. All authors have read and agreed to the published version of the manuscript.

Funding: This work was supported by the National Institute of Health (NIH) grants R01 AI121832 and R01 AI136514 (P.G.T.), the St. Jude Center of Excellence for Influenza Research and Surveillance (SJCEIRS) HHSN272201400006C (P.G.T.), and American Lebanese Syrian Associated Charities (ALSAC) (P.G.T.).

Acknowledgments: The authors would like to thank Stefan Schattgen for helpful discussion and feedback on the text and figure.

Conflicts of Interest: The authors declare no conflict of interest.

\section{Abbreviations}

$\begin{array}{ll}\text { pAg } & \text { phosphoantigen } \\ \text { HMB-PP } & (E) \text {-4-hydroxy-3-methyl-but-2-enyl pyrophosphate } \\ \text { IPP } & \text { isopentenyl pyrophosphate } \\ \text { HSCT } & \text { hematopoietic stem cell transplant } \\ \text { GVHD } & \text { graft-vs-host disease } \\ \text { HCMV } & \text { human cytomegalovirus } \\ \text { EPCR } & \text { endothelial protein C receptor }\end{array}$

\section{References}

1. Gaimann, M.U.; Nguyen, M.; Desponds, J.; Mayer, A. Early life imprints the hierarchy of T cell clone sizes. arXiv 2020, arXiv:2007.11113. [CrossRef]

2. Montecino-Rodriguez, E.; Berent-Maoz, B.; Dorshkind, K. Causes, consequences, and reversal of immune system aging. J. Clin. Investig. 2013, 123, 958-965. [CrossRef] [PubMed] 
3. Müller, L.; Fülöp, T.; Pawelec, G. Immunosenescence in vertebrates and invertebrates. Immun. Ageing 2013, 10, 12. [CrossRef] [PubMed]

4. Pawelec, G. Age and immunity: What is "immunosenescence"? Exp. Gerontol. 2018, 105, 4-9. [CrossRef] [PubMed]

5. Salam, N.; Rane, S.; Das, R.; Faulkner, M.; Gund, R.; Kandpal, U.; Lewis, V.; Mattoo, H.; Prabhu, S.; Ranganathan, V.; et al. T cell ageing: Effects of age on development, survival \& function. Indian J. Med. Res. 2013, 138, 595-608. [PubMed]

6. Shaw, A.C.; Goldstein, D.R.; Montgomery, R.R. Age-dependent dysregulation of innate immunity. Nat. Rev. Immunol. 2013, 13, 875-887. [CrossRef]

7. Simon, A.K.; Hollander, G.A.; McMichael, A. Evolution of the immune system in humans from infancy to old age. Proc. R. Soc. B Biol. Sci. 2015, 282, 20143085. [CrossRef] [PubMed]

8. Vasto, S.; Malavolta, M.; Pawelec, G. Age and immunity. Immun. Ageing 2006, 3, 2. [CrossRef]

9. Woodland, D.L.; Blackman, M.A. Immunity and age: Living in the past? Trends Immunol. 2006, 27, 303-307. [CrossRef]

10. Kollmann, T.R.; Levy, O.; Montgomery, R.R.; Goriely, S. Innate Immune Function by Toll-like Receptors: Distinct Responses in Newborns and the Elderly. Immunity 2012, 37, 771-783. [CrossRef]

11. Hill, D.L.; Carr, E.J.; Rutishauser, T.; Moncunill, G.; Campo, J.J.; Innocentin, S.; Mpina, M.; Nhabomba, A.; Tumbo, A.; Jairoce, C.; et al. Immune system development varies according to age, location, and anemia in African children. Sci. Transl. Med. 2020, 12, eaaw9522. [CrossRef] [PubMed]

12. Teran, R.; Mitre, E.; Vaca, M.; Erazo, S.; Oviedo, G.; Hübner, M.P.; Chico, M.E.; Mattapallil, J.J.; Bickle, Q.; Rodrigues, L.C.; et al. Immune system development during early childhood in tropical Latin America: Evidence for the age-dependent down regulation of the innate immune response. Clin. Immunol. 2011, 138, 299-310. [CrossRef] [PubMed]

13. Aiello, A.; Farzaneh, F.; Candore, G.; Caruso, C.; Davinelli, S.; Gambino, C.M.; Ligotti, M.E.; Zareian, N.; Accardi, G. Immunosenescence and Its Hallmarks: How to Oppose Aging Strategically? A Review of Potential Options for Therapeutic Intervention. Front. Immunol. 2019, 10, 2247. [CrossRef]

14. Graham, J.E.; Christian, L.M.; Kiecolt-Glaser, J.K. Stress, Age, and Immune Function: Toward a Lifespan Approach. J. Behav. Med. 2006, 29, 389-400. [CrossRef] [PubMed]

15. Alpert, A.; Pickman, Y.; Leipold, M.; Rosenberg-Hasson, Y.; Ji, X.; Gaujoux, R.; Rabani, H.; Starosvetsky, E.; Kveler, K.; Schaffert, S.; et al. A clinically meaningful metric of immune age derived from high-dimensional longitudinal monitoring. Nat. Med. 2019, 25, 487-495. [CrossRef]

16. Kalyan, S.; Kabelitz, D. Defining the nature of human $\gamma \delta \mathrm{T}$ cells: A biographical sketch of the highly empathetic. Cell. Mol. Immunol. 2013, 10, 21-29. [CrossRef]

17. Vantourout, P.; Hayday, A. Six-of-the-best: Unique contributions of $\gamma \delta$ T cells to immunology. Nat. Rev. Immunol. 2013, 13, 88-100. [CrossRef]

18. Xu, W.; Lau, Z.W.X.; Fulop, T.; Larbi, A. The Aging of $\gamma \delta$ T Cells. Cells 2020, 9, 1181. [CrossRef]

19. Schatz, D.G.; Swanson, P.C. V(D)J Recombination: Mechanisms of Initiation. Annu. Rev. Genet. 2011, 45, 167-202. [CrossRef]

20. Bradley, P.; Thomas, P.G. Using T Cell Receptor Repertoires to Understand the Principles of Adaptive Immune Recognition. Annu. Rev. Immunol. 2019, 37, 547-570. [CrossRef]

21. Brenner, M.B.; McLean, J.; Dialynas, D.P.; Strominger, J.L.; Smith, J.A.; Owen, F.L.; Seidman, J.G.; Ip, S.; Rosen, F.; Krangel, M.S. Identification of a putative second T-cell receptor. Nature 1986, 322, 145-149. [CrossRef] [PubMed]

22. Havran, W.L.; Allison, J.P. Developmentally ordered appearance of thymocytes expressing different T-cell antigen receptors. Nature 1988, 335, 443-445. [CrossRef] [PubMed]

23. Pardoll, D.M.; Fowlkes, B.J.; Bluestone, J.A.; Kruisbeek, A.; Maloy, W.L.; Coligan, J.E.; Schwartz, R.H. Differential expression of two distinct T-cell receptors during thymocyte development. Nature 1987, 326, 79-81. [CrossRef] [PubMed]

24. Chien, Y.; Meyer, C.; Bonneville, M. $\gamma \delta$ T Cells: First Line of Defense and Beyond. Annu. Rev. Immunol. 2014, 32, 121-155. [CrossRef]

25. Adams, E.J.; Gu, S.; Luoma, A.M. Human gamma delta T cells: Evolution and ligand recognition. Cell. Immunol. 2015, 296, 31-40. [CrossRef] 
26. Davey, M.S.; Willcox, C.R.; Baker, A.T.; Hunter, S.; Willcox, B.E. Recasting Human V $\delta 1$ Lymphocytes in an Adaptive Role. Trends Immunol. 2018, 39, 446-459. [CrossRef]

27. Khairallah, C.; Chu, T.H.; Sheridan, B.S. Tissue Adaptations of Memory and Tissue-Resident Gamma Delta T Cells. Front. Immunol. 2018, 9, 2636. [CrossRef]

28. Lefranc, M.-P.; Giudicelli, V.; Ginestoux, C.; Bodmer, J.; Müller, W.; Bontrop, R.; Lemaitre, M.; Malik, A.; Barbié, V.; Chaume, D. IMGT, the international ImMunoGeneTics database. Nucleic Acids Res. 1999, 27, 209-212. [CrossRef]

29. Carding, S.R.; Egan, P.J. $\gamma \delta$ T cells: Functional plasticity and heterogeneity. Nat. Rev. Immunol. 2002, 2, 336-345. [CrossRef]

30. Fichtner, A.S.; Ravens, S.; Prinz, I. Human $\gamma \delta$ TCR Repertoires in Health and Disease. Cells 2020, 9, 800. [CrossRef]

31. Liu, Y.; Zhang, C. The Role of Human $\gamma \delta$ T Cells in Anti-Tumor Immunity and Their Potential for Cancer Immunotherapy. Cells 2020, 9, 1206. [CrossRef] [PubMed]

32. Vavassori, S.; Kumar, A.; Wan, G.S.; Ramanjaneyulu, G.S.; Cavallari, M.; El Daker, S.; Beddoe, T.; Theodossis, A.; Williams, N.K.; Gostick, E.; et al. Butyrophilin 3A1 binds phosphorylated antigens and stimulates human $\gamma \delta$ T cells. Nat. Immunol. 2013, 14, 908-916. [CrossRef]

33. Willcox, C.R.; Vantourout, P.; Salim, M.; Zlatareva, I.; Melandri, D.; Zanardo, L.; George, R.; Kjaer, S.; Jeeves, M.; Mohammed, F.; et al. Butyrophilin-like 3 Directly Binds a Human V $\gamma 4+$ T Cell Receptor Using a Modality Distinct from Clonally-Restricted Antigen. Immunity 2019, 51, 813-825.e4. [CrossRef]

34. Hviid, L.; Akanmori, B.D.; Loizon, S.; Kurtzhals, J.A.L.; Ricke, C.H.; Lim, A.; Koram, K.A.; Nkrumah, F.K.; Mercereau-Puijalon, O.; Behr, C. High frequency of circulating $\gamma \delta$ T cells with dominance of the V $\delta 1$ subset in a healthy population. Int. Immunol. 2000, 12, 797-805. [CrossRef]

35. Hunter, S.; Willcox, C.R.; Davey, M.S.; Kasatskaya, S.A.; Jeffery, H.C.; Chudakov, D.M.; Oo, Y.H.; Willcox, B.E. Human liver infiltrating $\gamma \delta \mathrm{T}$ cells are composed of clonally expanded circulating and tissue-resident populations. J. Hepatol. 2018, 69, 654-665. [CrossRef] [PubMed]

36. Morita, C.T.; Parker, C.M.; Brenner, M.B.; Band, H. TCR usage and functional capabilities of human gamma delta T cells at birth. J. Immunol. 1994, 153, 3979-3988. [PubMed]

37. Lalor, S.J.; McLoughlin, R.M. Memory $\gamma \delta$ T Cells-Newly Appreciated Protagonists in Infection and Immunity. Trends Immunol. 2016, 37, 690-702. [CrossRef] [PubMed]

38. Pitard, V.; Roumanes, D.; Lafarge, X.; Couzi, L.; Garrigue, I.; Lafon, M.-E.; Merville, P.; Moreau, J.-F.; Déchanet-Merville, J. Long-term expansion of effector/memory V $\delta 2-\gamma \delta \mathrm{T}$ cells is a specific blood signature of CMV infection. Blood 2008, 112, 1317-1324. [CrossRef]

39. Willcox, B.E.; Willcox, C.R. $\gamma \delta$ TCR ligands: The quest to solve a 500-million-year-old mystery. Nat. Immunol. 2019, 20, 121-128. [CrossRef]

40. De Rosa, S.C.; Andrus, J.P.; Perfetto, S.P.; Mantovani, J.J.; Herzenberg, L.A.; Herzenberg, L.A.; Roederer, M. Ontogeny of gamma delta T cells in humans. J. Immunol. 2004, 172, 1637-1645. [CrossRef]

41. Li, Y.; Chen, S.; Yang, L.; Li, B.; Chan, J.Y.-H.; Cai, D. TRGV and TRDV repertoire distribution and clonality of T cells from umbilical cord blood. Transpl. Immunol. 2009, 20, 155-162. [CrossRef] [PubMed]

42. Papadopoulou, M.; Dimova, T.; Shey, M.; Briel, L.; Veldtsman, H.; Khomba, N.; Africa, H.; Steyn, M.; Hanekom, W.A.; Scriba, T.J.; et al. Fetal public V $\gamma 9 \mathrm{~V} \delta 2 \mathrm{~T}$ cells expand and gain potent cytotoxic functions early after birth. Proc. Natl. Acad. Sci. USA 2020, 117, 18638-18648. [CrossRef] [PubMed]

43. Vasudev, A.; Ying, C.T.T.; Ayyadhury, S.; Puan, K.J.; Andiappan, A.K.; Nyunt, M.S.Z.; Shadan, N.B.; Mustafa, S.; Low, I.; Rotzschke, O.; et al. $\gamma / \delta$ T cell subsets in human aging using the classical $\alpha / \beta$ T cell model. J. Leukoc. Biol. 2014, 96, 647-655. [CrossRef] [PubMed]

44. Dimova, T.; Brouwer, M.; Gosselin, F.; Tassignon, J.; Leo, O.; Donner, C.; Marchant, A.; Vermijlen, D. Effector V $\gamma 9$ V $\delta 2$ T cells dominate the human fetal $\gamma \delta$ T-cell repertoire. Proc. Natl. Acad. Sci. USA 2015, 112, E556-E565. [CrossRef] [PubMed]

45. Cairo, C.; Armstrong, C.L.; Cummings, J.S.; Deetz, C.O.; Tan, M.; Lu, C.; Davis, C.E.; Pauza, C.D. Impact of age, gender, and race on circulating $\gamma \delta$ T cells. Hum. Immunol. 2010, 71,968-975. [CrossRef] [PubMed]

46. Sant, S.; Jenkins, M.R.; Dash, P.; Watson, K.A.; Wang, Z.; Pizzolla, A.; Koutsakos, M.; Nguyen, T.H.; Lappas, M.; Crowe, J.; et al. Human $\gamma \delta$ T-cell receptor repertoire is shaped by influenza viruses, age and tissue compartmentalisation. Clin. Transl. Immunol. 2019, 8, e1079. [CrossRef]

47. Silva-Santos, B.; Strid, J. $\gamma \delta$ T cells get adaptive. Nat. Immunol. 2017, 18, 370-372. [CrossRef] 
48. Parker, C.M.; Groh, V.; Band, H.; Porcelli, S.A.; Morita, C.; Fabbi, M.; Glass, D.; Strominger, J.L.; Brenner, M.B. Evidence for extrathymic changes in the T cell receptor gamma/delta repertoire. J. Exp. Med. 1990, 171, 1597-1612. [CrossRef]

49. Michishita, Y.; Hirokawa, M.; Guo, Y.-M.; Abe, Y.; Liu, J.; Ubukawa, K.; Fujishima, N.; Fujishima, M.; Yoshioka, T.; Kameoka, Y.; et al. Age-associated alteration of $\gamma \delta$ T-cell repertoire and different profiles of activation-induced death of V $\delta 1$ and V $\delta 2 \mathrm{~T}$ cells. Int. J. Hematol. 2011, 94, 230-240. [CrossRef]

50. Wistuba-Hamprecht, K.; Haehnel, K.; Janssen, N.; Demuth, I.; Pawelec, G. Peripheral blood T-cell signatures from high-resolution immune phenotyping of $\gamma \delta$ and $\alpha \beta$ T-cells in younger and older subjects in the Berlin Aging Study II. Immun. Ageing 2015, 12, 25. [CrossRef]

51. Cairo, C.; Propp, N.; Auricchio, G.; Armstrong, C.L.; Abimiku, A.; Mancino, G.; Colizzi, V.; Blattner, W.; Pauza, C.D. Altered cord blood $\gamma \delta \mathrm{T}$ cell repertoire in Nigeria: Possible impacts of environmental factors on neonatal immunity. Mol. Immunol. 2008, 45, 3190-3197. [CrossRef] [PubMed]

52. Davey, M.S.; Willcox, C.R.; Hunter, S.; Kasatskaya, S.A.; Remmerswaal, E.B.M.; Salim, M.; Mohammed, F.; Bemelman, F.J.; Chudakov, D.M.; Oo, Y.H.; et al. The human V $\delta 2+$ T-cell compartment comprises distinct innate-like $\mathrm{V} \gamma 9+$ and adaptive $\mathrm{V} \gamma 9$-subsets. Nat. Commun. 2018, 9, 1760. [CrossRef] [PubMed]

53. De Rosa, S.C.; Mitra, D.K.; Watanabe, N.; Herzenberg, L.A.; Herzenberg, L.A.; Roederer, M. Vdelta1 and Vdelta2 gammadelta $\mathrm{T}$ cells express distinct surface markers and might be developmentally distinct lineages. J. Leukoc. Biol. 2001, 70, 518-526. [PubMed]

54. Colonna-Romano, G.; Potestio, M.; Aquino, A.; Candore, G.; Lio, D.; Caruso, C. Gamma/delta T lymphocytes are affected in the elderly. Exp. Gerontol. 2002, 37, 205-211. [CrossRef]

55. van der Heiden, M.; Björkander, S.; Rahman Qazi, K.; Bittmann, J.; Hell, L.; Jenmalm, M.C.; Marchini, G.; Vermijlen, D.; Abrahamsson, T.; Nilsson, C.; et al. Characterization of the $\gamma \delta$ T-cell compartment during infancy reveals clear differences between the early neonatal period and 2 years of age. Immunol. Cell Biol. 2020, 98, 79-87. [CrossRef]

56. Caccamo, N.; La Mendola, C.; Orlando, V.; Meraviglia, S.; Todaro, M.; Stassi, G.; Sireci, G.; Fournié, J.J.; Dieli, F. Differentiation, phenotype, and function of interleukin-17-producing human V $\gamma 9 \mathrm{~V} \delta 2 \mathrm{~T}$ cells. Blood 2011, 118, 129-138. [CrossRef]

57. Caccamo, N.; Battistini, L.; Bonneville, M.; Poccia, F.; Fournié, J.J.; Meraviglia, S.; Borsellino, G.; Kroczek, R.A.; Mendola, C.L.; Scotet, E.; et al. CXCR5 Identifies a Subset of V $\gamma 9$ V 22 T Cells which Secrete IL-4 and IL-10 and Help B Cells for Antibody Production. J. Immunol. 2006, 177, 5290-5295. [CrossRef]

58. Patil, R.S.; Bhat, S.A.; Dar, A.A.; Chiplunkar, S.V. The Jekyll and Hyde story of IL17 producing $\gamma \delta \mathrm{T}(\mathrm{T} \gamma \delta 17)$ cells. Front. Immunol. 2015, 6, 37. [CrossRef]

59. Mao, Y.; Yin, S.; Zhang, J.; Hu, Y.; Huang, B.; Cui, L.; Kang, N.; He, W. A new effect of IL-4 on human $\gamma \delta ~ T$ cells: Promoting regulatory V $\delta 1 \mathrm{~T}$ cells via IL-10 production and inhibiting function of V $\delta 2 \mathrm{~T}$ cells. Cell. Mol. Immunol. 2016, 13, 217-228. [CrossRef]

60. Agrati, C.; Alonzi, T.; De Santis, R.; Castilletti, C.; Abbate, I.; Capobianchi, M.R.; D’Offizi, G.; Siepi, F.; Fimia, G.M.; Tripodi, M.; et al. Activation of $\mathrm{V} \gamma 9 \mathrm{~V} \delta 2 \mathrm{~T}$ cells by non-peptidic antigens induces the inhibition of subgenomic HCV replication. Int. Immunol. 2006, 18, 11-18. [CrossRef]

61. Legut, M.; Cole, D.K.; Sewell, A.K. The promise of $\gamma \delta \mathrm{T}$ cells and the $\gamma \delta \mathrm{T}$ cell receptor for cancer immunotherapy. Cell. Mol. Immunol. 2015, 12, 656-668. [CrossRef] [PubMed]

62. Fan, D.-X.; Duan, J.; Li, M.-Q.; Xu, B.; Li, D.-J.; Jin, L.-P. The decidual gamma-delta T cells up-regulate the biological functions of trophoblasts via IL-10 secretion in early human pregnancy. Clin. Immunol. 2011, 141, 284-292. [CrossRef] [PubMed]

63. Bank, I. The Role of Gamma Delta T Cells in Autoimmune Rheumatic Diseases. Cells 2020, 9, 462. [CrossRef] [PubMed]

64. Zheng, J.; Liu, Y.; Lau, Y.-L.; Tu, W. $\gamma \delta$-T cells: An unpolished sword in human anti-infection immunity. Cell. Mol. Immunol. 2013, 10, 50-57. [CrossRef]

65. Qin, G.; Liu, Y.; Zheng, J.; Ng, I.H.Y.; Xiang, Z.; Lam, K.-T.; Mao, H.; Li, H.; Peiris, J.S.M.; Lau, Y.-L.; et al.

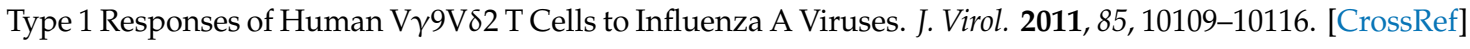

66. Dong, P.; Ju, X.; Yan, Y.; Zhang, S.; Cai, M.; Wang, H.; Chen, H.; Hu, Y.; Cui, L.; Zhang, J.; et al. $\gamma \delta$ T Cells Provide Protective Function in Highly Pathogenic Avian H5N1 Influenza A Virus Infection. Front. Immunol. 2018, 9, 2812. [CrossRef] 
67. Kroca, M.; Johansson, A.; Sjöstedt, A.; Tärnvik, A. V $\gamma 9$ V 22 T Cells in Human Legionellosis. Clin. Diagn. Lab. Immunol. 2001, 8, 949-954. [CrossRef]

68. Poccia, F.; Gioia, C.; Martini, F.; Sacchi, A.; Piacentini, P.; Tempestilli, M.; Agrati, C.; Amendola, A.; Abdeddaim, A.; Vlassi, C.; et al. Zoledronic acid and interleukin-2 treatment improves immunocompetence in HIV-infected persons by activating V $\gamma 9 \mathrm{~V} \delta 2 \mathrm{~T}$ cells. AIDS 2009, 23, 555-565. [CrossRef]

69. Laggner, U.; Meglio, P.D.; Perera, G.K.; Hundhausen, C.; Lacy, K.E.; Ali, N.; Smith, C.H.; Hayday, A.C.; Nickoloff, B.J.; Nestle, F.O. Identification of a Novel Proinflammatory Human Skin-Homing V $\gamma 9$ V $\delta 2$ T Cell Subset with a Potential Role in Psoriasis. J. Immunol. 2011, 187, 2783-2793. [CrossRef]

70. Corvaisier, M.; Moreau-Aubry, A.; Diez, E.; Bennouna, J.; Mosnier, J.-F.; Scotet, E.; Bonneville, M.; Jotereau, F. V $\gamma 9$ V82 T Cell Response to Colon Carcinoma Cells. J. Immunol. 2005, 175, 5481-5488. [CrossRef]

71. Chen, M.; Zhang, D.; Zhen, W.; Shi, Q.; Liu, Y.; Ling, N.; Peng, M.; Tang, K.; Hu, P.; Hu, H.; et al. Characteristics of Circulating T Cell Receptor $\gamma \delta$ T Cells from Individuals Chronically Infected with Hepatitis B Virus (HBV): An Association between V 22 Subtype and Chronic HBV Infection. J. Infect. Dis. 2008, 198, 1643-1650. [CrossRef] [PubMed]

72. Wu, X.; Zhang, J.-Y.; Huang, A.; Li, Y.-Y.; Zhang, S.; Wei, J.; Xia, S.; Wan, Y.; Chen, W.; Zhang, Z.; et al. Decreased V $\delta 2 \gamma \delta$ T Cells Associated with Liver Damage by Regulation of Th17 Response in Patients with Chronic Hepatitis B. J. Infect. Dis. 2013, 208, 1294-1304. [CrossRef] [PubMed]

73. Minculescu, L.; Sengeløv, H. The Role of Gamma Delta T Cells in Haematopoietic Stem Cell Transplantation. Scand. J. Immunol. 2015, 81, 459-468. [CrossRef] [PubMed]

74. Alejenef, A.; Pachnio, A.; Halawi, M.; Christmas, S.E.; Moss, P.A.H.; Khan, N. Cytomegalovirus drives V $\delta 2$ neg $\gamma \delta \mathrm{T}$ cell inflation in many healthy virus carriers with increasing age. Clin. Exp. Immunol. 2014, 176, 418-428. [CrossRef] [PubMed]

75. Szereday, L.; Baliko, Z.; Szekeres-Bartho, J. The role of V82+T-cells in patients with active Mycobacterium tuberculosis infection and tuberculin anergy. Int. J. Tuberc. Lung Dis. 2008, 12, 262-268.

76. Xi, X.; Han, X.; Li, L.; Zhao, Z. $\gamma \delta \mathrm{T}$ cells response to Mycobacterium tuberculosis in pulmonary tuberculosis patients using preponderant complementary determinant region 3 sequence. Indian J. Med. Res. 2011, 134, 356-361.

77. Cordova, A.; Toia, F.; Mendola, C.L.; Orlando, V.; Meraviglia, S.; Rinaldi, G.; Todaro, M.; Cicero, G.; Zichichi, L.; Donni, P.L.; et al. Characterization of Human $\gamma \delta$ T Lymphocytes Infiltrating Primary Malignant Melanomas. PLOS ONE 2012, 7, e49878. [CrossRef]

78. Ramstead, A.G.; Jutila, M.A. Complex Role of $\gamma \delta$ T-Cell-Derived Cytokines and Growth Factors in Cancer. J. Interferon Cytokine Res. 2012, 32, 563-569. [CrossRef]

79. Tseng, C.-T.K.; Miskovsky, E.; Houghton, M.; Klimpel, G.R. Characterization of liver T-cell receptor $\gamma \delta+$ $\mathrm{T}$ cells obtained from individuals chronically infected with hepatitis $\mathrm{C}$ virus (HCV): Evidence for these $\mathrm{T}$ cells playing a role in the liver pathology associated with HCV infections. Hepatology 2001, 33, 1312-1320. [CrossRef]

80. Rong, L.; Li, K.; Li, R.; Liu, H.-M.; Sun, R.; Liu, X.-Y. Analysis of tumor-infiltrating gamma delta T cells in rectal cancer. World J. Gastroenterol. 2016, 22, 3573-3580. [CrossRef]

81. Ma, C.; Zhang, Q.; Ye, J.; Wang, F.; Zhang, Y.; Wevers, E.; Schwartz, T.; Hunborg, P.; Varvares, M.A.; Hoft, D.F.; et al. Tumor-Infiltrating $\gamma \delta \mathrm{T}$ Lymphocytes Predict Clinical Outcome in Human Breast Cancer. J. Immunol. 2012, 189, 5029-5036. [CrossRef] [PubMed]

82. Fisch, P.; Malkovsky, M.; Kovats, S.; Sturm, E.; Braakman, E.; Klein, B.S.; Voss, S.D.; Morrissey, L.W.; DeMars, R.; Welch, W.J.; et al. Recognition by human V gamma 9/V delta $2 \mathrm{~T}$ cells of a GroEL homolog on Daudi Burkitt's lymphoma cells. Science 1990, 250, 1269-1273. [CrossRef] [PubMed]

83. Bennouna, J.; Bompas, E.; Neidhardt, E.M.; Rolland, F.; Philip, I.; Galéa, C.; Salot, S.; Saiagh, S.; Audrain, M.; Rimbert, M.; et al. Phase-I study of Innacell $\gamma \delta \mathrm{TM}$, an autologous cell-therapy product highly enriched in $\gamma 982 \mathrm{~T}$ lymphocytes, in combination with IL-2, in patients with metastatic renal cell carcinoma. Cancer Immunol. Immunother. 2008, 57, 1599-1609. [CrossRef] [PubMed]

84. Bonneville, M.; Scotet, E. Human V $\gamma 9 \mathrm{~V} \delta 2 \mathrm{~T}$ cells: Promising new leads for immunotherapy of infections and tumors. Curr. Opin. Immunol. 2006, 18, 539-546. [CrossRef]

85. Kabelitz, D.; Wesch, D.; Pitters, E.; Zöller, M. Characterization of Tumor Reactivity of Human V $\gamma 9 \mathrm{~V} \delta 2 \gamma \delta \mathrm{T}$ Cells In Vitro and in SCID Mice In Vivo. J. Immunol. 2004, 173, 6767-6776. [CrossRef] 
86. Lamb, L.S.; Lopez, R.D. $\gamma \delta$ T cells: A new frontier for immunotherapy? Biol. Blood Marrow Transplant. 2005, 11, 161-168. [CrossRef]

87. Meraviglia, S.; Eberl, M.; Vermijlen, D.; Todaro, M.; Buccheri, S.; Cicero, G.; Mendola, C.L.; Guggino, G.; D'Asaro, M.; Orlando, V.; et al. In vivo manipulation of V $\gamma 9 \mathrm{~V} \delta 2 \mathrm{~T}$ cells with zoledronate and low-dose interleukin-2 for immunotherapy of advanced breast cancer patients. Clin. Exp. Immunol. 2010, 161, 290-297. [CrossRef]

88. Rei, M.; Pennington, D.J.; Silva-Santos, B. The Emerging Protumor Role of $\gamma \delta$ T Lymphocytes: Implications for Cancer Immunotherapy. Cancer Res. 2015, 75, 798-802. [CrossRef]

89. Peng, G.; Wang, H.Y.; Peng, W.; Kiniwa, Y.; Seo, K.H.; Wang, R.-F. Tumor-Infiltrating $\gamma \delta$ T Cells Suppress T and Dendritic Cell Function via Mechanisms Controlled by a Unique Toll-like Receptor Signaling Pathway. Immunity 2007, 27, 334-348. [CrossRef]

90. Sullivan, L.C.; Shaw, E.M.; Stankovic, S.; I Snell, G.; Brooks, A.G.; Westall, G.P. The complex existence of $\gamma \delta \mathrm{T}$ cells following transplantation: The good, the bad and the simply confusing. Clin. Transl. Immunol. 2019, 8 , e1078. [CrossRef]

91. Arruda, L.C.M.; Gaballa, A.; Uhlin, M. Impact of $\gamma \delta \mathrm{T}$ cells on clinical outcome of hematopoietic stem cell transplantation: Systematic review and meta-analysis. Blood Adv. 2019, 3, 3436-3448. [CrossRef] [PubMed]

92. Perko, R.; Kang, G.; Sunkara, A.; Leung, W.; Thomas, P.G.; Dallas, M.H. Gamma Delta T Cell Reconstitution Is Associated with Fewer Infections and Improved Event-Free Survival after Hematopoietic Stem Cell Transplantation for Pediatric Leukemia. Biol. Blood Marrow Transplant. 2015, 21, 130-136. [CrossRef] [PubMed]

93. Ravens, S.; Schultze-Florey, C.; Raha, S.; Sandrock, I.; Drenker, M.; Oberdörfer, L.; Reinhardt, A.; Ravens, I.; Beck, M.; Geffers, R.; et al. Human $\gamma \delta$ T cells are quickly reconstituted after stem-cell transplantation and show adaptive clonal expansion in response to viral infection. Nat. Immunol. 2017, 18, 393-401. [CrossRef] [PubMed]

94. De Witte, M.A.; Sarhan, D.; Davis, Z.; Felices, M.; Vallera, D.A.; Hinderlie, P.; Curtsinger, J.; Cooley, S.; Wagner, J.; Kuball, J.; et al. Early Reconstitution of NK and $\gamma \delta$ T Cells and Its Implication for the Design of Post-Transplant Immunotherapy. Biol. Blood Marrow Transplant. 2018, 24, 1152-1162. [CrossRef]

95. Handgretinger, R.; Schilbach, K. The potential role of $\gamma \delta \mathrm{T}$ cells after allogeneic HCT for leukemia. Blood 2018, 131, 1063-1072. [CrossRef]

96. Fujishima, N.; Hirokawa, M.; Fujishima, M.; Yamashita, J.; Saitoh, H.; Ichikawa, Y.; Horiuchi, T.; Kawabata, Y.; Sawada, K.-I. Skewed $\mathrm{T}$ cell receptor repertoire of $\mathrm{V} \delta 1+\gamma \delta \mathrm{T}$ lymphocytes after human allogeneic haematopoietic stem cell transplantation and the potential role for Epstein-Barr virus-infected B cells in clonal restriction. Clin. Exp. Immunol. 2007, 149, 70-79. [CrossRef]

97. Lawand, M.; Déchanet-Merville, J.; Dieu-Nosjean, M.-C. Key Features of Gamma-Delta T-Cell Subsets in Human Diseases and Their Immunotherapeutic Implications. Front. Immunol. 2017, 8, 761. [CrossRef]

98. Sciammas, R.; Bluestone, J.A. TCR $\gamma \delta$ cells and viruses. Microbes Infect. 1999, 1, 203-212. [CrossRef]

99. Zhao, Y.; Lin, L.; Xiao, Z.; Li, M.; Wu, X.; Li, W.; Li, X.; Zhao, Q.; Wu, Y.; Zhang, H.; et al. Protective Role of $\gamma \delta$ T Cells in Different Pathogen Infections and Its Potential Clinical Application. Available online: https://www.hindawi.com/journals/jir/2018/5081634/ (accessed on 18 June 2020).

100. Jackson, S.E.; Redeker, A.; Arens, R.; van Baarle, D.; van den Berg, S.P.H.; Benedict, C.A.; Čičin-Šain, L.; Hill, A.B.; Wills, M.R. CMV immune evasion and manipulation of the immune system with aging. GeroScience 2017, 39, 273-291. [CrossRef]

101. Picarda, G.; Benedict, C.A. Cytomegalovirus: Shape-Shifting the Immune System. J. Immunol. 2018, 200, 3881-3889. [CrossRef]

102. Souquette, A.; Frere, J.; Smithey, M.; Sauce, D.; Thomas, P.G. A constant companion: Immune recognition and response to cytomegalovirus with aging and implications for immune fitness. GeroScience 2017, 39, 293-303. [CrossRef] [PubMed]

103. Khairallah, C.; Déchanet-Merville, J.; Capone, M. $\gamma \delta$ T Cell-Mediated Immunity to Cytomegalovirus Infection. Front. Immunol. 2017, 8, 105. [CrossRef] [PubMed]

104. About Cytomegalovirus and Congenital CMV Infection. Available online: https://www.cdc.gov/cmv/ overview.html (accessed on 23 November 2020). 
105. Bayard, C.; Lepetitcorps, H.; Roux, A.; Larsen, M.; Fastenackels, S.; Salle, V.; Vieillard, V.; Marchant, A.; Stern, M.; Boddaert, J.; et al. Coordinated expansion of both memory T cells and NK cells in response to CMV infection in humans. Eur. J. Immunol. 2016, 46, 1168-1179. [CrossRef] [PubMed]

106. van den Berg, S.P.H.; Pardieck, I.N.; Lanfermeijer, J.; Sauce, D.; Klenerman, P.; van Baarle, D.; Arens, R. The hallmarks of CMV-specific CD8 T-cell differentiation. Med. Microbiol. Immunol. 2019, 208, 365-373. [CrossRef] [PubMed]

107. Béziat, V.; Liu, L.L.; Malmberg, J.-A.; Ivarsson, M.A.; Sohlberg, E.; Björklund, A.T.; Retière, C.; Sverremark-Ekström, E.; Traherne, J.; Ljungman, P.; et al. NK cell responses to cytomegalovirus infection lead to stable imprints in the human KIR repertoire and involve activating KIRs. Blood 2013, 121, 2678-2688. [CrossRef] [PubMed]

108. Faist, B.; Fleischer, B.; Jacobsen, M. Cytomegalovirus Infection- and Age-Dependent Changes in Human CD8+ T-Cell Cytokine Expression Patterns. Clin. Vaccine Immunol. 2010, 17, 986-992. [CrossRef]

109. Goodier, M.R.; Jonjić, S.; Riley, E.M.; Lisnić, V.J. CMV and natural killer cells: Shaping the response to vaccination. Eur. J. Immunol. 2018, 48, 50-65. [CrossRef]

110. Wallace, D.L.; Masters, J.E.; de Lara, C.M.; Henson, S.M.; Worth, A.; Zhang, Y.; Kumar, S.R.; Beverley, P.C.; Akbar, A.N.; Macallan, D.C. Human cytomegalovirus-specific CD8+ T-cell expansions contain long-lived cells that retain functional capacity in both young and elderly subjects. Immunology 2011, 132, 27-38. [CrossRef]

111. Déchanet, J.; Merville, P.; Lim, A.; Retière, C.; Pitard, V.; Lafarge, X.; Michelson, S.; Méric, C.; Hallet, M.-M.; Kourilsky, P.; et al. Implication of $\gamma \delta \mathrm{T}$ cells in the human immune response to cytomegalovirus. J. Clin. Investig. 1999, 103, 1437-1449. [CrossRef]

112. Kallemeijn, M.J.; Boots, A.M.H.; van der Klift, M.Y.; Brouwer, E.; Abdulahad, W.H.; Verhaar, J.A.N.; van Dongen, J.J.M.; Langerak, A.W. Ageing and latent CMV infection impact on maturation, differentiation and exhaustion profiles of T-cell receptor gammadelta T-cells. Sci. Rep. 2017, 7, 5509. [CrossRef]

113. Déchanet, J.; Merville, P.; Bergé, F.; Bone-Mane, G.; Taupin, J.-L.; Michel, P.; Joly, P.; Bonneville, M.; Potaux, L.; Moreau, J.-F. Major Expansion of $\gamma \delta \mathrm{T}$ Lymphocytes following Cytomegalovirus Infection in Kidney Allograft Recipients. J. Infect. Dis. 1999, 179, 1-8. [CrossRef] [PubMed]

114. Knight, A.; Madrigal, A.J.; Grace, S.; Sivakumaran, J.; Kottaridis, P.; Mackinnon, S.; Travers, P.J.; Lowdell, M.W. The role of V $\delta 2$-negative $\gamma \delta$ T cells during cytomegalovirus reactivation in recipients of allogeneic stem cell transplantation. Blood 2010, 116, 2164-2172. [CrossRef] [PubMed]

115. Roux, A.; Mourin, G.; Larsen, M.; Fastenackels, S.; Urrutia, A.; Gorochov, G.; Autran, B.; Donner, C.; Sidi, D.; Sibony-Prat, J.; et al. Differential Impact of Age and Cytomegalovirus Infection on the $\gamma \delta \mathrm{T}$ Cell Compartment. J. Immunol. 2013, 191, 1300-1306. [CrossRef] [PubMed]

116. Wistuba-Hamprecht, K.; Frasca, D.; Blomberg, B.; Pawelec, G.; Derhovanessian, E. Age-associated alterations in $\gamma \delta$ T-cells are present predominantly in individuals infected with Cytomegalovirus. Immun. Ageing 2013, 10, 26. [CrossRef] [PubMed]

117. Vermijlen, D.; Brouwer, M.; Donner, C.; Liesnard, C.; Tackoen, M.; Van Rysselberge, M.; Twité, N.; Goldman, M.; Marchant, A.; Willems, F. Human cytomegalovirus elicits fetal $\gamma \delta$ T cell responses in utero. J. Exp. Med. 2010, 207, 807-821. [CrossRef]

118. Halary, F.; Pitard, V.; Dlubek, D.; Krzysiek, R.; de la Salle, H.; Merville, P.; Dromer, C.; Emilie, D.; Moreau, J.-F.; Déchanet-Merville, J. Shared reactivity of V $\delta 2$ neg $\gamma \delta$ T cells against cytomegalovirus-infected cells and tumor intestinal epithelial cells. J. Exp. Med. 2005, 201, 1567-1578. [CrossRef]

119. Willcox, C.R.; Pitard, V.; Netzer, S.; Couzi, L.; Salim, M.; Silberzahn, T.; Moreau, J.-F.; Hayday, A.C.; Willcox, B.E.; Déchanet-Merville, J. Cytomegalovirus and tumor stress surveillance by binding of a human $\gamma \delta \mathrm{T}$ cell antigen receptor to endothelial protein C receptor. Nat. Immunol. 2012, 13, 872-879. [CrossRef]

120. Frasca, D.; Blomberg, B.B. Aging, cytomegalovirus (CMV) and influenza vaccine responses. Hum. Vaccines Immunother. 2016, 12, 682-690. [CrossRef]

121. Merani, S.; Pawelec, G.; Kuchel, G.A.; McElhaney, J.E. Impact of Aging and Cytomegalovirus on Immunological Response to Influenza Vaccination and Infection. Front. Immunol. 2017, 8, 784. [CrossRef]

122. Oshansky, C.M.; Gartland, A.J.; Wong, S.-S.; Jeevan, T.; Wang, D.; Roddam, P.L.; Caniza, M.A.; Hertz, T.; DeVincenzo, J.P.; Webby, R.J.; et al. Mucosal Immune Responses Predict Clinical Outcomes during Influenza Infection Independently of Age and Viral Load. Am. J. Respir. Crit. Care Med. 2013, 189, 449-462. [CrossRef]

123. Castle, S.C. Clinical Relevance of Age-Related Immune Dysfunction. Clin. Infect. Dis. 2000, 31, 578-585. [CrossRef] [PubMed] 
124. Furman, D.; Jojic, V.; Sharma, S.; Shen-Orr, S.S.; Angel, C.J.L.; Onengut-Gumuscu, S.; Kidd, B.A.; Maecker, H.T.; Concannon, P.; Dekker, C.L.; et al. Cytomegalovirus infection enhances the immune response to influenza. Sci. Transl. Med. 2015, 7, 281ra43. [CrossRef] [PubMed]

125. Qin, G.; Mao, H.; Zheng, J.; Sia, S.F.; Liu, Y.; Chan, P.-L.; Lam, K.-T.; Peiris, J.S.M.; Lau, Y.-L.; Tu, W. Phosphoantigen-Expanded Human $\gamma \delta$ T Cells Display Potent Cytotoxicity against Monocyte-Derived Macrophages Infected with Human and Avian Influenza Viruses. J. Infect. Dis. 2009, 200, 858-865. [CrossRef] [PubMed]

126. Qin, G.; Liu, Y.; Zheng, J.; Xiang, Z.; Ng, I.H.Y.; Malik Peiris, J.S.; Lau, Y.-L.; Tu, W. Phenotypic and Functional Characterization of Human $\gamma \delta$ T-Cell Subsets in Response to Influenza A Viruses. J. Infect. Dis. 2012, 205, 1646-1653. [CrossRef] [PubMed]

127. Li, H.; Xiang, Z.; Feng, T.; Li, J.; Liu, Y.; Fan, Y.; Lu, Q.; Yin, Z.; Yu, M.; Shen, C.; et al. Human V $\gamma 9$ V82-T cells efficiently kill influenza virus-infected lung alveolar epithelial cells. Cell. Mol. Immunol. 2013, 10, 159-164. [CrossRef]

128. Tu, W.; Zheng, J.; Liu, Y.; Sia, S.F.; Liu, M.; Qin, G.; Ng, I.H.Y.; Xiang, Z.; Lam, K.-T.; Peiris, J.S.M.; et al. The aminobisphosphonate pamidronate controls influenza pathogenesis by expanding a $\gamma \delta \mathrm{T}$ cell population in humanized mice. J. Exp. Med. 2011, 208, 1511-1522. [CrossRef]

129. Stervbo, U.; Pohlmann, D.; Baron, U.; Bozzetti, C.; Jürchott, K.; Mälzer, J.N.; Nienen, M.; Olek, S.; Roch, T.; Schulz, A.R.; et al. Age dependent differences in the kinetics of $\gamma \delta \mathrm{T}$ cells after influenza vaccination. PLoS ONE 2017, 12, e0181161. [CrossRef]

130. McArdle, A.J.; Turkova, A.; Cunnington, A.J. When do co-infections matter? Curr. Opin. Infect. Dis. 2018, 31, 209-215. [CrossRef]

131. Souquette, A.; Thomas, P.G. Past Life and Future Effects-How Heterologous Infections Alter Immunity to Influenza Viruses. Front. Immunol. 2018, 9, 1071. [CrossRef]

132. Balbi, B.; Valle, M.T.; Oddera, S.; Giunti, O.; Manca, F.; Rossi, G.A.; Allegra, L. T-Lymphocytes with $\gamma \delta+$ V 2 + Antigen Receptors Are Present in Increased Proportions in a Fraction of Patients with Tuberculosis or with Sarcoidosis. Am. Rev. Respir. Dis. 1993, 148, 1685-1690. [CrossRef]

133. Janis, E.M.; Kaufmann, S.H.; Schwartz, R.H.; Pardoll, D.M. Activation of gamma delta T cells in the primary immune response to Mycobacterium tuberculosis. Science 1989, 244, 713-716. [CrossRef] [PubMed]

134. Meraviglia, S.; El Daker, S.; Dieli, F.; Martini, F.; Martino, A. $\gamma \delta$ T Cells Cross-Link Innate and Adaptive Immunity in Mycobacterium Tuberculosis Infection. Available online: https://www.hindawi.com/journals/ jir/2011/587315/ (accessed on 14 August 2020).

135. Ding, Y.; Ma, F.; Wang, Z.; Li, B. Characteristics of the V $\delta 2$ CDR3 Sequence of Peripheral $\gamma \delta \mathrm{T}$ Cells in Patients with Pulmonary Tuberculosis and Identification of a New Tuberculosis-Related Antigen Peptide. Clin. Vaccine Immunol. 2015, 22, 761-768. [CrossRef] [PubMed]

136. Cheng, C.; Wang, B.; Gao, L.; Liu, J.; Chen, X.; Huang, H.; Zhao, Z. Next generation sequencing reveals changes of the $\gamma \delta \mathrm{T}$ cell receptor repertoires in patients with pulmonary tuberculosis. Sci. Rep. 2018, 8, 3956. [CrossRef] [PubMed]

137. Xi, X.; Han, X.; Li, L.; Zhao, Z. Identification of a New Tuberculosis Antigen Recognized by $\gamma \delta$ T Cell Receptor. Clin. Vaccine Immunol. 2013, 20, 530-539. [CrossRef]

138. Constant, P.; Poquet, Y.; Peyrat, M.A.; Davodeau, F.; Bonneville, M.; Fournié, J.J. The antituberculous Mycobacterium bovis BCG vaccine is an attenuated mycobacterial producer of phosphorylated nonpeptidic antigens for human gamma delta T cells. Infect. Immun. 1995, 63, 4628-4633. [CrossRef]

139. Shen, Y.; Zhou, D.; Qiu, L.; Lai, X.; Simon, M.; Shen, L.; Kou, Z.; Wang, Q.; Jiang, L.; Estep, J.; et al. Adaptive Immune Response of V $\gamma 2 \mathrm{~V} \delta 2+\mathrm{T}$ Cells During Mycobacterial Infections. Science 2002, 295, 2255-2258. [CrossRef]

140. Cairo, C.; Mancino, G.; Cappelli, G.; Pauza, C.D.; Galli, E.; Brunetti, E.; Colizzi, V. V 22 T-lymphocyte responses in cord blood samples from Italy and Côte d'Ivoire. Immunology 2008, 124, 380-387. [CrossRef]

141. Panchamoorthy, G.; McLean, J.; Modlin, R.L.; Morita, C.T.; Ishikawa, S.; Brenner, M.B.; Band, H. A predominance of the $\mathrm{T}$ cell receptor $\mathrm{V}$ gamma 2/V delta 2 subset in human mycobacteria-responsive $\mathrm{T}$ cells suggests germline gene encoded recognition. J. Immunol. 1991, 147, 3360-3369.

142. Vesosky, B.; Turner, J. The influence of age on immunity to infection with Mycobacterium tuberculosis. Immunol. Rev. 2005, 205, 229-243. [CrossRef] 
143. Vesosky, B.; Flaherty, D.K.; Rottinghaus, E.K.; Beamer, G.L.; Turner, J. Age dependent increase in early resistance of mice to Mycobacterium tuberculosis is associated with an increase in CD8 T cells that are capable of antigen independent IFN- $\gamma$ production. Exp. Gerontol. 2006, 41, 1185-1194. [CrossRef]

144. Piergallini, T.J.; Turner, J. Tuberculosis in the elderly: Why inflammation matters. Exp. Gerontol. 2018, 105, 32-39. [CrossRef] [PubMed]

145. Eberl, M.; Roberts, G.W.; Meuter, S.; Williams, J.D.; Topley, N.; Moser, B. A Rapid Crosstalk of Human $\gamma \delta ~ T$ Cells and Monocytes Drives the Acute Inflammation in Bacterial Infections. PLoS Pathog. 2009, 5, e1000308. [CrossRef] [PubMed]

146. Puan, K.-J.; Jin, C.; Wang, H.; Sarikonda, G.; Raker, A.M.; Lee, H.K.; Samuelson, M.I.; Märker-Hermann, E.; Pasa-Tolic, L.; Nieves, E.; et al. Preferential recognition of a microbial metabolite by human V $\gamma 2 \mathrm{~V} \delta 2 \mathrm{~T}$ cells. Int. Immunol. 2007, 19, 657-673. [CrossRef] [PubMed]

147. Wu, Y.-L.; Ding, Y.-P.; Tanaka, Y.; Shen, L.-W.; Wei, C.-H.; Minato, N.; Zhang, W. $\gamma \delta$ T Cells and Their Potential for Immunotherapy. Int. J. Biol. Sci. 2014, 10, 119-135. [CrossRef]

148. Pauza, C.D.; Poonia, B.; Li, H.; Cairo, C.; Chaudhry, S. $\gamma \delta$ T Cells in HIV Disease: Past, Present, and Future. Front. Immunol. 2015, 5, 687. [CrossRef] [PubMed]

149. Juno, J.A.; Eriksson, E.M. $\gamma \delta$ T-cell responses during HIV infection and antiretroviral therapy. Clin. Transl. Immunol. 2019, 8, e01069. [CrossRef]

150. Belkina, A.C.; Starchenko, A.; Drake, K.A.; Proctor, E.A.; Pihl, R.M.F.; Olson, A.; Lauffenburger, D.A.; Lin, N.; Snyder-Cappione, J.E. Multivariate Computational Analysis of Gamma Delta T cell Inhibitory Receptor Signatures Reveals the Divergence of Healthy and ART-Suppressed HIV+ Aging. Front. Immunol. 2018, 9, 2783. [CrossRef]

151. Fang, H.; Welte, T.; Zheng, X.; Chang, G.-J.J.; Holbrook, M.R.; Soong, L.; Wang, T. $\gamma \delta d$ T cells promote the maturation of dendritic cells during West Nile virus infection. FEMS Immunol. Med. Microbiol. 2010, 59, 71-80. [CrossRef]

152. Kallemeijn, M.J.; Kavelaars, F.G.; van der Klift, M.Y.; Wolvers-Tettero, I.L.M.; Valk, P.J.M.; van Dongen, J.J.M.; Langerak, A.W. Next-Generation Sequencing Analysis of the Human TCR $\gamma \delta+$ T-Cell Repertoire Reveals Shifts in $\mathrm{V} \gamma$ - and $\mathrm{V} \delta$-Usage in Memory Populations upon Aging. Front. Immunol. 2018, 9, 448. [CrossRef]

153. Lei, L.; Qian, H.; Yang, X.; Zhang, X.; Zhang, D.; Dai, T.; Guo, R.; Shi, L.; Cheng, Y.; Zhang, B.; et al. The phenotypic changes of $\gamma \delta \mathrm{T}$ cells in COVID-19 patients. J. Cell. Mol. Med. 2020, 24, 11603-11606. [CrossRef]

154. Deroost, K.; Langhorne, J. Gamma/Delta T Cells and Their Role in Protection Against Malaria. Front. Immunol. 2018, 9, 2973. [CrossRef] [PubMed]

155. Chen, Z.; Freedman, M.S. CD16 $+\gamma \delta$ T cells mediate antibody dependent cellular cytotoxicity: Potential mechanism in the pathogenesis of multiple sclerosis. Clin. Immunol. 2008, 128, 219-227. [CrossRef] [PubMed]

156. Ito, Y.; Usui, T.; Kobayashi, S.; Iguchi-Hashimoto, M.; Ito, H.; Yoshitomi, H.; Nakamura, T.; Shimizu, M.; Kawabata, D.; Yukawa, N.; et al. Gamma/delta T cells are the predominant source of interleukin-17 in affected joints in collagen-induced arthritis, but not in rheumatoid arthritis. Arthritis Rheum. 2009, 60, 2294-2303. [CrossRef] [PubMed]

157. Papotto, P.H.; Reinhardt, A.; Prinz, I.; Silva-Santos, B. Innately versatile: $\gamma \delta 17$ T cells in inflammatory and autoimmune diseases. J. Autoimmun. 2018, 87, 26-37. [CrossRef] [PubMed]

Publisher's Note: MDPI stays neutral with regard to jurisdictional claims in published maps and institutional affiliations.

(C) 2020 by the authors. Licensee MDPI, Basel, Switzerland. This article is an open access article distributed under the terms and conditions of the Creative Commons Attribution (CC BY) license (http://creativecommons.org/licenses/by/4.0/). 